\title{
Biogeochemical variations at the Porcupine Abyssal Plain sustained Observatory in the northeast Atlantic Ocean, from weekly to inter-annual timescales
}

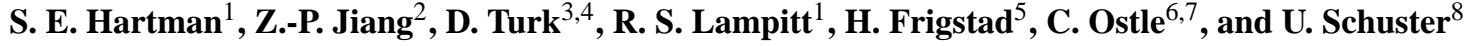 \\ ${ }^{1}$ National Oceanography Centre, Southampton, SO14 3ZH, UK \\ ${ }^{2}$ Ocean Collage, Zhejiang University, 310012 Hangzhou, China \\ ${ }^{3}$ Dalhousie University, Halifax, B3H 4R2, Canada \\ ${ }^{4}$ Lamont-Doherty Earth Observatory, Palisades, NY 10964, USA \\ ${ }^{5}$ Norwegian Environment Agency, 0663 Oslo, Norway \\ ${ }^{6}$ Sir Alister Hardy Foundation for Ocean Science, Plymouth, PL1 2PB, UK \\ ${ }^{7}$ School of Environmental Sciences, University of East Anglia, Norwich, NR4 7TJ, UK \\ ${ }^{8}$ University of Exeter, Exeter, EX4 4PS, UK \\ Correspondence to: S. E. Hartman (suh@noc.ac.uk)
}

Received: 30 June 2014 - Published in Biogeosciences Discuss.: 19 August 2014

Revised: 19 December 2014 - Accepted: 22 December 2014 - Published: 12 February 2015

\begin{abstract}
We present high-resolution autonomous measurements of carbon dioxide partial pressure $p\left(\mathrm{CO}_{2}\right)$ taken in situ at the Porcupine Abyssal Plain sustained Observatory (PAP-SO) in the northeast Atlantic $\left(49^{\circ} \mathrm{N}, 16.5^{\circ} \mathrm{W}\right.$; water depth of $4850 \mathrm{~m}$ ) for the period 2010-2012. Measurements of $p\left(\mathrm{CO}_{2}\right)$ made at $30 \mathrm{~m}$ depth on a sensor frame are compared with other autonomous biogeochemical measurements at that depth (including chlorophyll $a$ fluorescence and nitrate concentration data) to analyse weekly to seasonal controls on $p\left(\mathrm{CO}_{2}\right)$ flux in the inter-gyre region of the North Atlantic. Comparisons are also made with in situ regional time series data from a ship of opportunity and mixed layer depth (MLD) measurements from profiling Argo floats. There is a persistent under-saturation of $\mathrm{CO}_{2}$ in surface waters throughout the year which gives rise to a perennial $\mathrm{CO}_{2}$ sink. Comparison with an earlier data set collected at the site (20032005) confirms seasonal and inter-annual changes in surface seawater chemistry. There is year-to-year variability in the timing of deep winter mixing and the intensity of the spring bloom.

The 2010-2012 period shows an overall increase in $p\left(\mathrm{CO}_{2}\right)$ values when compared to the 2003-2005 period as would be expected from increases due to anthropogenic $\mathrm{CO}_{2}$ emissions. The surface temperature, wind speed and MLD measurements are similar for both periods of time. Future
\end{abstract}

work should incorporate daily $\mathrm{CO}_{2}$ flux measurements made using $\mathrm{CO}_{2}$ sensors at $1 \mathrm{~m}$ depth and the in situ wind speed data now available from the UK Met Office Buoy.

\section{Introduction}

A persistent feature of the subpolar North Atlantic is under-saturation of carbon dioxide $\left(\mathrm{CO}_{2}\right)$ in surface waters throughout the year, which gives rise to a perennial $\mathrm{CO}_{2}$ sink (Körtzinger et al., 2008). This makes the north east Atlantic a region of great importance in the global carbon cycle. There is evidence for inter-annual variation in the $\mathrm{CO}_{2}$ sink (1-3 mol m $\left.\mathrm{m}^{-2} \mathrm{a}^{-1}\right)$ due to changes in wintertime mixing and stratification (Schuster and Watson, 2007). Changes in the amount of $\mathrm{CO}_{2}$ absorbed by the ocean may have implications for the global carbon cycle now and for the role of the ocean as a carbon sink in the future. Studies of the physical and biological processes regulating surface water $p\left(\mathrm{CO}_{2}\right)$ (partial pressure of $\mathrm{CO}_{2}$ ) are required to estimate future trends in the ability of the ocean to act as a sink for increasing $\mathrm{CO}_{2}$ in the atmosphere. Frequent observations from fixed positions are critical to make these calculations (McGillicuddy et al., 1998). 
Accurate, high-resolution, long-term data sets are offered by time series studies such as the Porcupine Abyssal Plain sustained Observatory (PAP-SO) in the northeast Atlantic at $49^{\circ} \mathrm{N}, 16.5^{\circ} \mathrm{W}(4850 \mathrm{~m}$ water depth) where a fixed-point mooring has been in place since 2002 (Hartman et al., 2012). The PAP-SO is in the North Atlantic Drift Region, a biogeographical province defined by deep winter convective mixing (Longhurst, 2006; Monterey and Levitus, 1997). The surface mixed layer depth can change from $25 \mathrm{~m}$ in the summer to over $400 \mathrm{~m}$ in winter. A 2 -fold decrease in winter nitrate concentration over a 3-year period from 2003 has been attributed to a combination of shallower winter convective mixing and changes in surface circulation (Hartman et al., 2010). The PAP-SO is in an area with relatively high wind speeds, frequently greater than $10 \mathrm{~m} \mathrm{~s}^{-1}$. High wind speeds have a significant effect on $\mathrm{CO}_{2}$ flux (Takahashi et al., 2002). The $\mathrm{CO}_{2}$ flux at the PAP-SO was calculated from $p\left(\mathrm{CO}_{2}\right)$, between 2003 and 2005 as a net flux into the ocean of over $3 \mathrm{~mol} \mathrm{~m}^{-2} \mathrm{a}^{-1}$ (Körtzinger et al., 2008). This is a significant sink compared with subtropical time series sites such as ESTOC (near the Canary Islands, $29.17^{\circ} \mathrm{N}, 15.5^{\circ} \mathrm{W}$ ), which is an overall annual $\mathrm{CO}_{2}$ source region $\left(0.05 \mathrm{~mol} \mathrm{~m}^{-2} \mathrm{a}^{-1}\right.$, González-Dávila et al., 2003).

Recently, the decline in North Atlantic $\mathrm{CO}_{2}$ uptake from 1994-1995 to 2002-2005 has been linked to a variation in the North Atlantic Oscillation (Schuster and Watson, 2007; Padin et al., 2011). The decreased uptake may be a consequence of declining rates of wintertime mixing and ventilation between surface and subsurface waters due to increasing stratification. Enhanced stratification forms a barrier to nutrient exchange, which may result in a progressive decline in primary production (Field et al., 1998), as was seen in the North Atlantic between 1999 and 2004 (Behrenfeld et al., 2006). The observed decrease in nitrate concentration and productivity in this region (Behrenfeld et al., 2006), may in turn affect the oceanic uptake of $p\left(\mathrm{CO}_{2}\right)$.

In this paper, we present recent year round time series data of temperature, salinity, nitrate concentration, chlorophyll $a$ fluorescence and $p\left(\mathrm{CO}_{2}\right)$ collected at $30 \mathrm{~m}$ depth from May 2010 to June 2012. The data are compared with an earlier published data set (from July 2003 to July 2005) and additional $p\left(\mathrm{CO}_{2}\right)$ measurements made from a ship of opportunity. The in situ data set is considered in relation to convective mixing processes using mixed layer depth (MLD) estimates calculated from profiling Argo floats. The weekly airsea $\mathrm{CO}_{2}$ flux at the PAP-SO site was calculated from in situ $p\left(\mathrm{CO}_{2}\right)$ measurements and ancillary satellite wind speed data sets. The objective of this study is to examine the biogeochemical variations at the PAP-SO in the northeast Atlantic over different periods from weekly, seasonal to annual.

\section{Materials and methods}

\subsection{Study site}

The position of the PAP-SO at $49^{\circ} \mathrm{N}, 16.5^{\circ} \mathrm{W}$ is shown in Fig. 1. Lampitt et al. (2001) has summarised the hydrography, meteorology and upper mixed layer dynamics in the region.

\subsection{In situ data}

The instrumentation of the PAP-SO has been described in detail by Hartman et al., 2012 (see Table 1 and Fig. 1 therein) and is briefly summarised here. Since 2002 instruments on a mooring at the PAP-SO $\left(49^{\circ} \mathrm{N}, 16.5^{\circ} \mathrm{W}\right)$ have recorded a suite of parameters in the mixed layer. Temperature and salinity measurements were made on a frame at a nominal depth of $30 \mathrm{~m}$, using Seabird SBE 37-IM MicroCAT recorders (Sea-Bird Electronics Inc., Bellevue, Washington, USA). Measurements of nitrate concentration, chlorophyll $a$ fluorescence and $p\left(\mathrm{CO}_{2}\right)$, were also made using biogeochemical sensors on the frame, often within the deep chlorophyll maximum. Between 2002 and 2007 the sensor frame depth varied from 20 to $225 \mathrm{~m}$, deflecting in response to local currents. A surface buoy was added in 2007 so that measurements were consistently made at $30 \mathrm{~m}$ depth. In 2010, collaboration with the UK Met Office led to a redesigned infrastructure, providing simultaneous surface physical and biogeochemical measurements with surface meteorological data.

$p\left(\mathrm{CO}_{2}\right)$ data during the two periods of time examined here were collected using different instrumentation. From 2003 to 2005 it was measured using a SAMI (Sunburst Sensors LLC, USA) sensor, which is based on equilibration of a $\mathrm{pH}$ indicator solution, contained in a gas-permeable membrane, with ambient $p\left(\mathrm{CO}_{2}\right)$ and subsequent spectrophotometric determination in the equilibrated solution (DeGrandpre et al., 1995). Twice daily $p\left(\mathrm{CO}_{2}\right)$ measurements, from 2010 to 2012, were made using a membrane-based PRO$\mathrm{CO} 2$ sensor (Pro-Oceanus, Canada), which uses an infrared detector and is internally calibrated through an auto-zero calibration function (Jiang et al., 2014). Note that a measurement error of an early version of the PRO-CO2 sensor during the deployment, induced by the fluctuation of detector cell temperature, was identified and corrected (see Jiang et al., 2014 for further details). A pump was used (Seabird Inc.) to improve water flow across the sensor membrane to accelerate attaining equilibrium. The surface in situ $p\left(\mathrm{CO}_{2}\right)$ time series ceased between 2006 and 2009 due to funding issues.

Although measured by different instruments, the two $p\left(\mathrm{CO}_{2}\right)$ data sets were calibrated in a similar way to make them comparable: the sensor outputs were calibrated against $p\left(\mathrm{CO}_{2}\right)$ values calculated from dissolved inorganic carbon (DIC) and total alkalinity (TA) from discrete samples taken at the mooring site during deployment/recovery cruises; and 


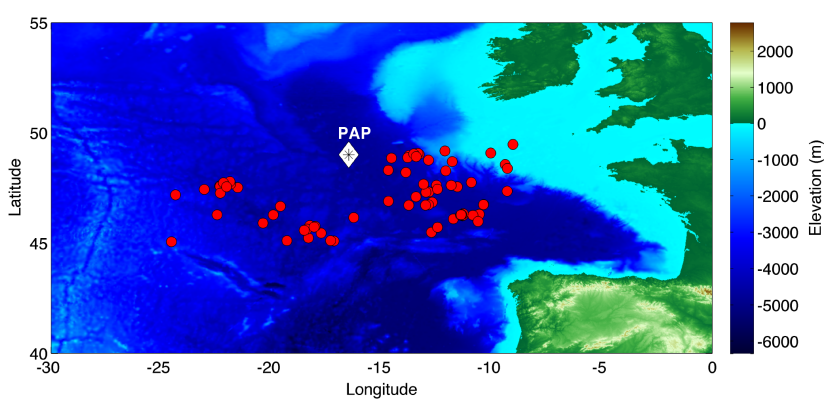

Figure 1. Map of the inter-gyre region of the northeast Atlantic showing the bathymetry around the PAP observatory (white diamond) and the ship of opportunity (SOO) sampling positions (red circles) from 2010 to 2012.

plausibility checks were made with underway $p\left(\mathrm{CO}_{2}\right)$ measurements around the PAP site. The 2003-2005 data were previously published (see Körtzinger et al., 2008 for details) with a precision of $1 \mu \mathrm{atm}$ and accuracy estimated as 6-10 $\mu$ atm. The 2010-2012 data have a similar precision $(1 \mu \mathrm{atm})$ and accuracy $(6 \mu \mathrm{atm})$.

A Hobi Labs Inc., HS-2 fluorometer (Arizona, USA) was used on the PAP-SO mooring to estimate chlorophyll $a$ concentration until 2005 when an alternative ECO FLNTU (WETlab, USA) fluorometer came into use. The quoted precision for fluorescence measured by these fluorometers is $0.04 \%$, however as described by Hartman et al. (2010), fluorescence output can only provide an approximation of the chlorophyll $a$ concentration. The fluorescence/chlorophyll $a$ concentration ratio changes throughout the year, due to variations in the phytoplankton species composition. On the mooring, chlorophyll $a$ fluorescence measurements were taken every $2 \mathrm{~h}$ over the 1 year deployments and biofouling was controlled using motorised copper shutters on each of the fluorometers.

Nitrate concentration measurements were initially made using wet chemical NAS Nitrate Analysers (EnviroTech LLC, USA), precision $0.2 \mu \mathrm{mol} \mathrm{L}^{-1}$, as described in Hydes et al. (2000), with twice daily sampling frequency and internal calibration as described by Hartman et al. (2010). From 2010 additional higher frequency inorganic nitrate measurements were made using UV detection methods (ISUS, Satlantic), with a precision of $1 \mu \mathrm{molL} \mathrm{L}^{-1}$.

For each instrument, the manufacturer's calibration was checked at the start of each deployment and a correction for instrument drift was made using a second calibration check on recovery of the instruments. Biogeochemical data from the PAP-SO are available from EuroSITES (2014) and the British Oceanographic Data Centre (BODC). Data presented here cover the period when $p\left(\mathrm{CO}_{2}\right)$ measurements are available, July 2003 to the end of June 2005 (with deployments in July 2003, November 2003, June 2004) and the period from May 2010 to June 2012 (with sensor deployment in May 2010, September 2010, July 2011, May 2012). All of the measurements are within the mixed layer although the depth of measurements is closer to the $30 \mathrm{~m}$ nominal depth after mooring redesign to incorporate a surface float in 2007.

\subsection{Other observational data sources}

Temperature and salinity data were taken from Argo floats (http://www.coriolis.eu.org), extracting $(30 \pm 5) \mathrm{m}$ depth data. To obtain a continuous seasonal description, a large region around the PAP site was selected $\left(45-52^{\circ} \mathrm{N}\right.$ and 26.08 $8.92^{\circ} \mathrm{W}$, excluding the shelf area). The Argo data have a potentially lower accuracy $\left(0.005^{\circ} \mathrm{C}\right.$ for temperature and 0.1 for salinity) than the in situ MicroCAT data ( 0.002 for salinity and $0.002{ }^{\circ} \mathrm{C}$ for temperature). However the Argo data were chosen over the in situ data for all calculations as they have a larger temporal coverage and are internally consistent.

The $p\left(\mathrm{CO}_{2}\right)$ time series was compared with surface data from a ship of opportunity (SOO) running from Portsmouth, UK, to the Caribbean (Schuster and Watson, 2007). Onboard the $\mathrm{SOO}$ continuous $p\left(\mathrm{CO}_{2}\right)$ measurements are made using a calibrated system with a showerhead equilibrator (Schuster et al., 2009). Data are available from the Surface Ocean $\mathrm{CO}_{2}$ Atlas (SOCAT; http://www.socat.info/). Discrete nutrient samples were collected at $4 \mathrm{~h}$ intervals along the same route and were analysed ashore (Hartman et al., 2008). This provides an approximately monthly nutrient sample and $p\left(\mathrm{CO}_{2}\right)$ data points close to the PAP-SO on the return route of the ship. The nominal depth of these samples is $5 \mathrm{~m}$, which is shallower than the $30 \mathrm{~m}$ samples from the PAP-SO. We selected SOO data between 52 and $45^{\circ} \mathrm{N}$ and 8.92 and $26.08^{\circ} \mathrm{W}$, and then took the average $p\left(\mathrm{CO}_{2}\right)$ values that were within that area on the same day as the sample from the PAPSO site.

Through collaboration with the UK Met Office in situ wind speed data are available since 2010. However for consistency in calculations of $\mathrm{CO}_{2}$ flux between the two time periods (2003-2005 and 2010-2012) considered here we took wind speed data from weekly satellite data: Fleet Numerical Meteorology and Oceanography Center (FNMOC) $1^{\circ}$ by $1^{\circ}$. We calculated a weekly mean from the 6 hourly, $10 \mathrm{~m}$ height data; available from http://las.pfeg.noaa.gov/.

The air-sea $\mathrm{CO}_{2}$ flux (in mmol m${ }^{-2} \mathrm{~d}^{-1}$ ) was calculated from the air-sea $p\left(\mathrm{CO}_{2}\right)$ difference, temperature and salinity $(30 \mathrm{~m})$ and wind speed at $10 \mathrm{~m}$ height, using the following equation:

$F\left(\mathrm{CO}_{2}\right)=k \cdot K_{0}\left[p\left(\mathrm{CO}_{2}\right.\right.$, sea $)-p\left(\mathrm{CO}_{2}\right.$, air $\left.)\right]$,

where $k$ is the transfer coefficient based on the wind speeddependent formulation of Nightingale et al. (2000), scaled to the temperature-dependent Schmidt number according to Wanninkhof (1992), $K_{0}$ is the $\mathrm{CO}_{2}$ solubility at the in situ temperature and salinity after Weiss (1974). While $p\left(\mathrm{CO}_{2}\right.$, sea) and $p\left(\mathrm{CO}_{2}\right.$, air) are the $\mathrm{CO}_{2}$ partial pressures of seawater and average $\mathrm{CO}_{2}$ dry mole fraction measured in air, respectively. As $p\left(\mathrm{CO}_{2}\right)$ was reported throughout this 
manuscript, we used $p\left(\mathrm{CO}_{2}\right)$ for the air-sea flux calculation. Using fugacity for the calculation would generate the same results of flux estimates. The atmospheric $p\left(\mathrm{CO}_{2}\right)$ is calculated from monthly averaged $p\left(\mathrm{CO}_{2}\right)$ measured at Mace Head $\left(53.33^{\circ} \mathrm{N}, 9.90^{\circ} \mathrm{W}\right)$ assuming $100 \%$ water vapour saturation under $1 \mathrm{~atm}$ air pressure. Please note that $1 \mathrm{~atm}$ $=1.01325$ bar. This is an appropriate pressure to use at the PAP-SO as the average (and standard deviation) of the air pressure, measured on the buoy at the PAP-SO between September 2010 and July 2011, was (1.01354 \pm 13.14$)$ bar.

Total alkalinity (TA) was calculated from Argo temperature and salinity $(30 \mathrm{~m})$, following the relationship for the North Atlantic developed by Lee et al. (2006) with an uncertainty of $\pm 6.4 \mu \mathrm{mol} \mathrm{kg}^{-1}$ (Lee et al., 2006). The DIC concentration was then calculated from TA and $p\left(\mathrm{CO}_{2}\right)$ using the "seacarb" package (Lavigne and Gattuso, 2011), with Argo temperature and salinity $(30 \mathrm{~m})$ and nutrient concentrations set to zero. The chosen constants were Lueker et al. (2000) for $K_{2}$ and $K_{2}$, Perez and Fraga (1987) for $K_{\mathrm{f}}$ and the Dickson (1990) constant for $K_{\mathrm{s}}$, as recommended by Dickson et al. (2007). We followed Körtzinger et al. (2008)'s method to correct the DIC changes driven by air-sea exchange:

$\Delta \mathrm{DIC}_{\text {gas }}=F\left(\mathrm{CO}_{2}\right) / \mathrm{MLD}$.

Using TA and $p\left(\mathrm{CO}_{2}\right)$ to calculate DIC, and taking the various uncertainties in the calculation into account, introduces an error in the order of $7.0 \mu \mathrm{mol} \mathrm{kg}-1$.

The MLD was calculated from density profiles using global gridded fields of temperature and salinity collected by Argo floats, XBTs, CTDs and moorings. These data are collected and made freely available by the Coriolis project and programmes that contribute to it (http://www.coriolis.eu. org). We used the near real-time mode data as these data sets have been quality control checked. Before deciding on a MLD definition an inter-comparison of many definitions commonly used in the literature was done such as density differences, temperature differences and density gradients (Kara et al., 2000; Thomson and Fine, 2003; Montegut et al., 2004). A subset of the global density profiles calculated from the gridded temperature and salinity fields was used to compare the different methods. The depth of the mixed layer was estimated through visual inspection of over 3000 profiles, following a similar approach used by Fiedler (2010). The Holte and Talley (2009) density difference algorithm gave the closest match with the visually estimated MLD (RMSD $29.38 \mathrm{~m}$ ). The depth of the mixed layer was defined by a density difference of $0.03 \mathrm{~kg} \mathrm{~m}^{-3}$ from the density at a reference depth (in this case $10 \mathrm{~m}$ to avoid diurnal changes in temperature and salinity at the surface). This Holte and Talley (2009) density difference algorithm incorporates linear interpolation to estimate the depth at which the density difference is crossed.

The North Atlantic Oscillation (NAO) index (after Hurrell, 1995) was obtained from the University of East Anglia web site http://www.cru.uea.ac.uk/cru/data/nao/.

\section{Results}

Figure $2 \mathrm{a}-\mathrm{c}$ show the in situ observations from the PAPSO at $30 \mathrm{~m}$ depth, including $p\left(\mathrm{CO}_{2}\right)$, chlorophyll $a$ fluorescence and nitrate concentration. Figure $2 \mathrm{a}$ shows the range of $p\left(\mathrm{CO}_{2}\right)$ from 2003 to 2005 , which was also shown in Körtzinger et al. (2008). The range was $74 \mu \mathrm{atm}$ (300$374 \mu \mathrm{atm})$ and the mean was $339 \mu \mathrm{atm}$. In comparison, $p\left(\mathrm{CO}_{2}\right)$ between 2010 and 2012 had a $57 \mu$ atm range (327 to $384 \mu \mathrm{atm})$ with a higher mean of $353 \mu \mathrm{atm}$. The $p\left(\mathrm{CO}_{2}\right)$ data for the 2010-2012 period are confirmed by SOO data from the Portsmouth to Caribbean route in Fig. 2a (see Fig. 1 for positions of the SOO samples). Körtzinger et al. (2008) also reported a good comparison with a SOO route from Kiel, to the north of the Portsmouth to Caribbean route, for the 20032005 data. The SOO data fill in the gap in the time series when PAP-SO $p\left(\mathrm{CO}_{2}\right)$ data were not available due to failure of the instrument logger. The higher $p\left(\mathrm{CO}_{2}\right)$ values in the 2010-2012 period are confirmed by the SOO data.

In situ chlorophyll data in Fig. $2 \mathrm{~b}$ shows the characteristic chlorophyll $a$ fluorescence increase for this area during the spring bloom. There is large inter-annual variability in both the timing and magnitude of the spring bloom for the two time periods shown. For example the spring bloom in 2004 started in late May compared with an earlier bloom in 2011 (that started in April). The increase in chlorophyll $a$ fluorescence during the 2011 spring bloom was also larger compared with the other years shown.

Nitrate concentration data in Fig. 2c shows the characteristic seasonality, with increased winter nitrate concentrations and depletion following the spring bloom (seen in Fig. 2b). The seasonality in the nitrate concentration is similar for the two periods shown (2003-2005 and 2010-2012). SOO nitrate concentration data show a good agreement with the PAP-SO data throughout 2010-2012 and fill in the gaps in early 2011 when nutrient measurements at the PAP-SO are not available. Overall, the in situ data show a characteristic increase in inorganic nitrate concentrations, and $p\left(\mathrm{CO}_{2}\right)$, through the winter as fluorescence decreases. However, winter nitrate concentrations are significantly lower in the 2004/05 winter compared with other years as has been discussed in Hartman et al. (2010).

Figure 3a shows the Argo temperature data extracted at $30 \mathrm{~m}$ depth and the in situ MicroCAT temperature data at the PAP-SO. Temperature shows opposite seasonal variations to the $p\left(\mathrm{CO}_{2}\right)$ and nitrate concentration from in situ data. A comparison of Argo temperature with in situ $30 \mathrm{~m}$ MicroCAT data $(n=112$, comparison not shown) suggests errors of up to $1 \%$ for temperature in the Argo data compared with the in situ data (when available). Both data sets show that the temperature variations in these years are very similar, showing a summer-winter difference of $6^{\circ} \mathrm{C}$ (Fig. 3a).

The seasonality of the in situ data can be put in context when looking at the MLD in Fig. 3b. The increase in $p\left(\mathrm{CO}_{2}\right)$ and nitrate concentration corresponds to deeper convective 


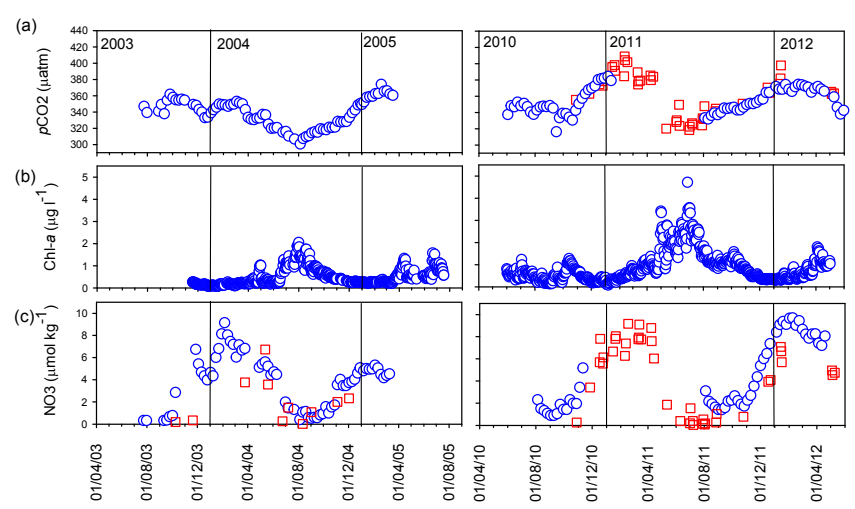

Figure 2. In situ $30 \mathrm{~m}$ PAP-SO data (blue circles) from 2003 to 2005 and 2010 to 2012 and $5 \mathrm{~m}$ SOO data (red squares) with vertical lines to represent the start of each year showing: (a) $p\left(\mathrm{CO}_{2}\right)$; (b) chlorophyll $a$ concentration; (c) weekly-averaged nitrate concentration.

mixing in winter. The MLD range varies little over the winters considered here (Fig. 3b) and the maximum MLD does not exceed $260 \mathrm{~m}$. However the timing of the maximum winter mixed layer depth at PAP-SO varies from year to year. For example the maximum MLD (Fig. 3b) for the 2010/11 winter reached $215 \mathrm{~m}$ in February 2011 compared with earlier and deeper mixing (to $257 \mathrm{~m}$ ) in the following 2011/12 winter (December 2011).

The calculated DIC concentrations (Fig. 3c) show a closer relationship to the MLD seasonality than nitrate concentration data. Seasonal variation in the concentration of both DIC and nitrate is similar apart from the 2004/05 winter; when low DIC concentrations were not seen at the same time as the low nitrate concentrations (Fig. 3c).

The interrelation between DIC and nitrate concentrations can be considered by comparing the $\mathrm{C}: \mathrm{N}$ ratios to the Redfield ratio (Redfield, 1958). The 2003-2005 time period has already been considered in Körtzinger et al. (2008) so is not reproduced here. Following Körtzinger et al. (2008) we calculated DIC, corrected for gas exchange. DIC concentrations were plotted against the in situ nitrate concentrations in different seasons for 2010-2012 (Fig. 4). The C:N ratio differed from the Redfield ratio of 6.6 with especially high values in spring (14.3).

Figure 5a shows weekly satellite wind speed data used to calculate the $\mathrm{CO}_{2}$ flux. The wind speeds were similar in the two periods. There is an earlier period of days with high wind speeds towards the end of 2011 that can be compared with the $\mathrm{CO}_{2}$ data presented. The annual average wind speed was $8.2 \mathrm{~m} \mathrm{~s}^{-1}$ for both time periods. The maximum was $14 \mathrm{~m} \mathrm{~s}^{-1}$, although in situ winds of up to $20 \mathrm{~m} \mathrm{~s}^{-1}$ were seen from the Met Office data (eurosites.info/pap), this is not seen in the weekly averaged satellite wind speed data presented.

Figure $5 \mathrm{~b}$ shows the sea-to-air $\mathrm{CO}_{2}$ flux (where a positive flux is defined as from sea to the atmosphere). This was calculated from in situ $p\left(\mathrm{CO}_{2}\right)$ data and satellite wind speed

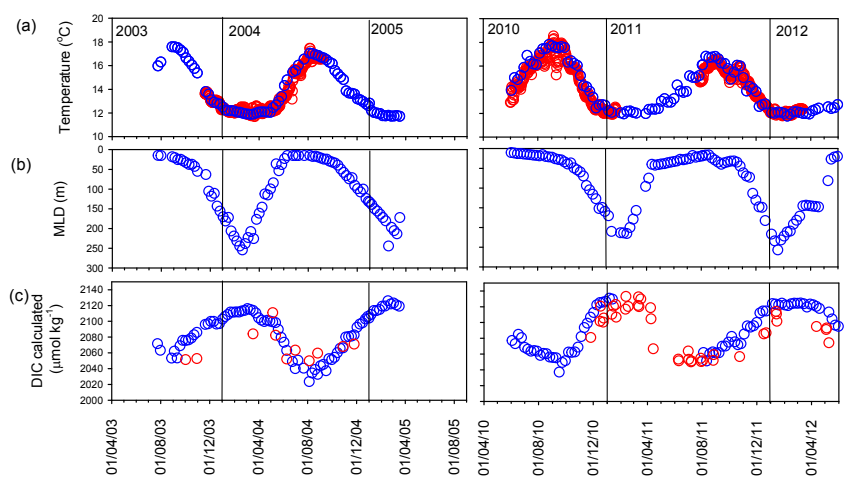

Figure 3. Data from 2003 to 2005 and 2010 to 2012 (blue circles) with vertical lines to represent the start of each year showing: (a) Argo temperature data from $30 \mathrm{~m}$ depth around the PAP-SO and in situ MicroCAT temperature data at $30 \mathrm{~m}$ (red circles); (b) calculated mixed layer depth (MLD) data; (c) calculations of weekly dissolved inorganic carbon (DIC) concentrations based on in situ PAP-SO $p\left(\mathrm{CO}_{2}\right)$ and salinity-based TA parameterisations (see text for details) with additional DIC calculations based on SOO data (red circles).

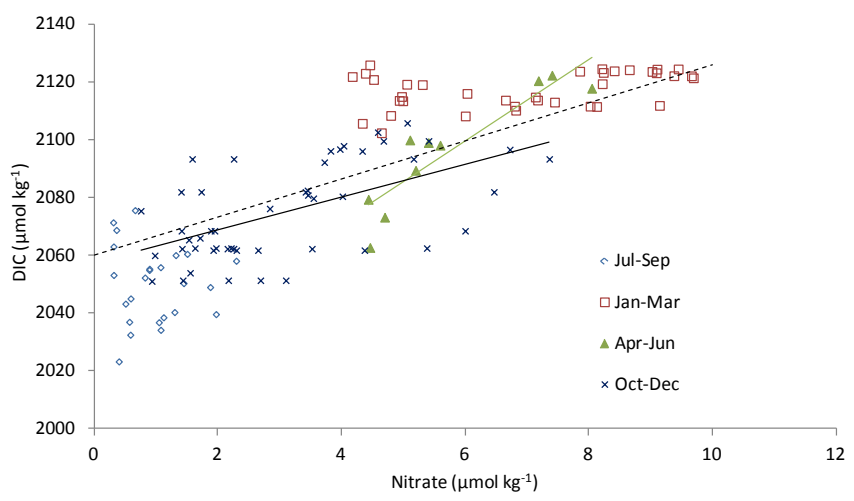

Figure 4. The relationship between concentrations of gas exchangecorrected DIC and nitrate (2010-2012) at the PAP-SO showing 4 different seasons: winter (January-March, red squares); spring (April-June, green triangles); summer (July-September, blue diamonds); autumn (October-December, dark blue crosses). The green line shows the ratio in spring (14.3) and the blue line is the ratio in autumn (6.4), with the Redfield ratio of 6.6 shown for reference as a dashed line.

data (Fig. 5b). The week by week variation in $\mathrm{CO}_{2}$ flux is shown and an overall average for the two periods of time has been calculated as $(-5.7 \pm 2.8) \mathrm{mmol} \mathrm{m}^{-2} \mathrm{~d}^{-1}$ for the 2003 2005 period and $(-5.0 \pm 2.2) \mathrm{mmol} \mathrm{m}^{-2} \mathrm{~d}^{-1}$ for the 2010 2012 period. SOO data have been used at the start of 2011 when in situ $p\left(\mathrm{CO}_{2}\right)$ data were unavailable. The start and end months of the two periods of time differs, which will contribute to the errors in the flux measurements. However the errors are comparable for the two periods of time considered and overall the average for the two time periods is similar. 


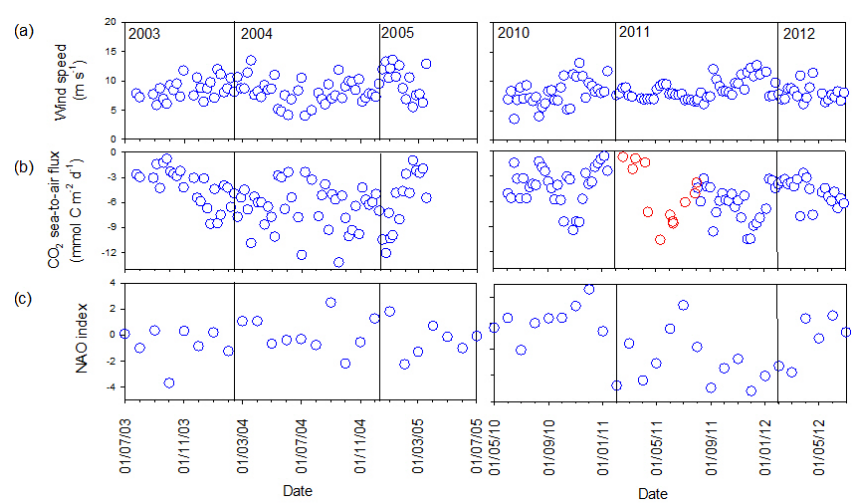

Figure 5. Data from 2003 to 2005 and 2010 to 2012 (blue circles) for (a) weekly satellite wind data in the region of the PAP-SO; (b) calculations of weekly sea-to-air $\mathrm{CO}_{2}$ flux (negative: into the ocean) from in situ PAP-SO $p\left(\mathrm{CO}_{2}\right)$ data and satellite wind (see text for details) with additional flux calculations from SOO data (red circles); (c) the monthly NAO index.

There is little variation in $\mathrm{CO}_{2}$ flux and MLD between the years shown but for completeness the NAO index is shown in Fig. 5c. The 2003/04 winter NAO was near zero and the 2004/05 winter NAO was also low, between -2 to +1 . In contrast there is a large range in the winter NAO in the 2010/11 winter when the NAO changed from -4 to +3 . Overall the range in the NAO values was larger for the 20102012 time period shown.

\section{Discussion}

\subsection{PAP-SO seasonal variation}

The 2003-2005 and 2010-2013 data sets show very similar seasonal patterns between the years. Concentrations of nitrate and DIC exhibit seasonal variations opposite to temperature. The seasonal variation in nitrate and DIC concentrations is controlled by convective mixing (resulting in the winter maximum) and biological uptake during the spring bloom period (resulting in the summer minimum), which is similar to elsewhere in the North Atlantic (Jiang et al., 2013).

The $p\left(\mathrm{CO}_{2}\right)$ distribution pattern at the PAP-SO site is characterised by a single annual peak (high in winter and low in summer), which is similar to that of nutrient and DIC concentrations, but in antiphase to the temperature signal. Jiang et al. (2013) compared seasonal carbon variability between different sites in the North Atlantic and suggested a latitudinal change in $p\left(\mathrm{CO}_{2}\right)$ seasonality from the temperaturedominated oligotrophic subtropical gyre to the subpolar region where $p\left(\mathrm{CO}_{2}\right)$ is dominated by changing concentrations of DIC. Our $p\left(\mathrm{CO}_{2}\right)$ observations at the PAP-SO site show the subpolar-like seasonal pattern, which is similar to that of the ocean weather station M (Skjelvan et al., 2008). The surface $p\left(\mathrm{CO}_{2}\right)$ is mainly governed by the varying DIC concentration while the seasonal cooling and warming have a contrasting effect.
The time integrated uptake of DIC and nitrate during the spring bloom is reflected by the slope of the linear regression between them (Fig. 4). The ratio of DIC and nitrate concentrations from 2010 to 2012 shows higher values than the Redfield $\mathrm{C}: \mathrm{N}$ ratio of 6.6 . For example the spring-time ratio of $14.3( \pm 5)$ was considerably higher than the Redfield ratio, in agreement with similar "carbon overconsumption" ratios seen for the North Atlantic (e.g. 14.2, Sambrotto et al., 1993). This value is in agreement with the single $\mathrm{C}: \mathrm{N}$ ratio reported previously at the PAP-SO of 11.0 (Körtzinger et al., 2008). In both cases the DIC concentrations were calculated and therefore associated with errors in the order of $7.0 \mu \mathrm{mol} \mathrm{kg}{ }^{-1}$. We have demonstrated seasonal variation in the $\mathrm{C}: \mathrm{N}$ ratio at the PAP-SO, with an autumn $\mathrm{C}: \mathrm{N}$ value that is closer to the Redfield ratio and large deviations from the Redfield ratio in winter.

\subsection{Air-sea $\mathrm{CO}_{2}$ flux}

Wind speeds have an indirect impact on the biogeochemistry, in particular $p\left(\mathrm{CO}_{2}\right)$. In the North Atlantic the strength and frequency of wintertime storms is significantly increasing (Donat et al., 2011). Wind speeds are similar for the two time periods considered here. However there is some suggestion of an earlier increase in winds at the start of the 2011/12 winter (Fig. 5a) coinciding with an earlier increase in mixing (Fig. 3b). Although the $\mathrm{CO}_{2}$ flux is not linked linearly to the wind speed there is a corresponding decrease in $\mathrm{CO}_{2}$ flux into the ocean at this time.

It is well known that the northeast Atlantic is a strong $\mathrm{CO}_{2}$ sink with large variability. The observations at the PAP-SO provide high frequency data to follow the variability in $\mathrm{CO}_{2}$ exchange. The largest $\mathrm{CO}_{2}$ flux shown here was in September 2004, as a combined result of low seawater $p\left(\mathrm{CO}_{2}\right)$ (Fig. 2a) and high wind speed (Fig. 5b). Larger $\mathrm{CO}_{2}$ flux into the ocean may have occurred in 2011 considering the large, early spring bloom seen in that year but we do not have in situ PAP-SO $p\left(\mathrm{CO}_{2}\right)$ data to calculate the flux at that time. However flux calculations from SOO data in early 2011 do not suggest an increase in $\mathrm{CO}_{2}$ flux. Increases in productivity do not necessarily result in enhanced oceanic $\mathrm{CO}_{2}$ uptake as the gas exchange is also affected by other factors such as temperature and wind speed (Jiang et al., 2013). The average is similar for the years presented with values of $-5.7 \mathrm{mmol} \mathrm{m}^{-2} \mathrm{~d}^{-1}$ in 2003-2005 and $-5.0 \mathrm{mmol} \mathrm{m}^{-2} \mathrm{~d}^{-1}$ from 2010 to 2012.

\subsection{PAP-SO inter-annual variations}

It is suggested that NAO plays an important role in modulating the inter-annual variability in the northeast Atlantic region by affecting the intensity of winter convection (Bennington et al., 2009; Jiang et al., 2013). The Gibraltar minus Iceland version of the NAO index is really most applicable to the winter half of the year. During positive NAO periods, the PAP-SO region experiences subpolar-like conditions, 
with strong wind stress and deep mixed layers (Henson et al., 2012). However the MLD did not vary significantly at the PAP-SO between the 2003-2005 and 2010-2012 time periods shown here (with a range of only $215-257 \mathrm{~m}$ for deepest winter MLD between the years. In previous years such as 2009/10 deep winter mixing of $390 \mathrm{~m}$ has been seen with an NAO reaching -3 , (not shown). NAO is unlikely to have a large role at the PAP-SO as winter sea surface temperature and MLD were similar in the time periods 2003-2005 and 2010-2012. Data from a winter with deeper mixing would need to be put into the comparison to resolve this.

There was a 2-fold decrease in nitrate concentrations in the 2004-2005 winter despite sea surface temperature and MLD values being close to other years. The low values were confirmed by SOO data, also shown in Hartman et al. (2010). As discussed in Hartman et al. (2010) the lower winter nitrate concentration seen in 2004/05 did not correlate with a decrease in the MLD and this showed the influence of horizontal mixing at the PAP-SO. It was suggested that lateral advection to the site at that time introduced a subtropical water mass with a lower nitrate concentration. Earlier time series studies largely ignored circulation at the PAPSO site, assuming convective mixing is a dominant process influencing mixed layer temperature and nitrate concentrations in the region (Williams et al., 2000; Körtzinger et al., 2008). However, fixed-point time series observations are influenced by spatial variability passing the point of observation (McGillicuddy et al., 1998; Painter et al., 2010). It is clear from Hartman et al. (2010) that lateral advection may significantly influence the surface temperature and nitrate concentrations in the region of the PAP-SO site.

The observed seawater $p\left(\mathrm{CO}_{2}\right)$ increased from $(339 \pm$ 17) $\mu$ atm in 2003-2005 to $(353 \pm 15) \mu a t m$ in 2010-2012, which largely agrees with the increasing rate of surface seawater $p\left(\mathrm{CO}_{2}\right)$ observed in the North Atlantic basin of $(1.84 \pm 0.4) \mu \mathrm{atm} \mathrm{a}^{-1}$ (Takahashi et al., 2009). Despite similar maximum winter MLD in 2003-2005 and 2010-2012, the timing and intensity of the spring bloom is quite different and the cause of this requires further investigation.

\section{Conclusions and further work}

We have presented recent year-round surface time series biogeochemical data at the PAP-SO and compared it with previous observations. The surface $p\left(\mathrm{CO}_{2}\right)$, and concentrations of DIC and nitrate, at the PAP-SO all show a clear seasonal cycle, which is mainly controlled by winter convective mixing and biological activity in the spring bloom. However the suggestion that inter-annual variability is dominated by convection (Bennington et al., 2009) is not clear as the MLD did not vary significantly between the winter periods shown. An especially low winter nitrate concentration in 2005 was observed, thought to be due to surface advection and this highlights the need to consider advection when dealing with time series data in the future. Despite the similar winter physical conditions (temperature and MLD), there is a year to year difference in the timing and intensity of the spring blooms, which requires further investigation. At PAP-SO, increasing mean seawater $p\left(\mathrm{CO}_{2}\right)$ from $(339 \pm 17) \mu \mathrm{atm}$ in 2003 to $(353 \pm 15) \mu \mathrm{atm}$ in 2011 was observed. However the mean air-sea $\mathrm{CO}_{2}$ flux did not show a significant change. It varied from $(-5.7 \pm 2.8) \mathrm{mmol} \mathrm{m}^{-2} \mathrm{~d}^{-1}$ in $2003-2005$ to $(-5.0 \pm 2.2) \mathrm{mmol} \mathrm{m}^{-2} \mathrm{~d}^{-1}$ in 2010-2012.

In 2010, collaboration between the UK's Natural Environment Research Council (NERC) and Meteorological Office led to the first simultaneous monitoring of in situ meteorological and ocean variables at the PAP-SO (Hartman et al., 2012). From 2013 additional measurements of $p\left(\mathrm{CO}_{2}\right)$ will be made at the site, at the shallower depth of $1 \mathrm{~m}$, and should further improve the SOO comparison. The site could be used to investigate the effect of different parameterisations (Prytherch et al., 2010) and wind products on calculations of $\mathrm{CO}_{2}$ flux, in particular during the high wind conditions seen. Using the contemporaneous atmospheric and ocean data sets we will be able to investigate the effect of storms on $\mathrm{CO}_{2}$ flux and resolve daily variability.

Acknowledgements. We would like to acknowledge the various ship crew, engineers and scientists involved in preparation, deployment and recovery of the PAP-SO moorings. We would especially like to thank J. Campbell, M. Hartman and M. Pagnani for the PAP time series and H. Cole who calculated MLD from the Argo float data. The research leading to these results was supported through the EU FP7 project CARBOCHANGE "Changes in carbon uptake and emissions by oceans in a changing climate", which received funding from the European Commission's Seventh Framework Programme under grant agreement no. 264879. Funding that supports the running of the SOO network used in this project also includes EU grant 212196 (CO-COS), and UK NERC grant NE/H017046/1 (UKOARP); Funding for part of this study was provided by NERC CASE studentship grant reference number NE/J500069/1 in collaboration with SAHFOS. Argo data were made freely available by the Coriolis project and programmes that contribute to it http://www.coriolis.eu.org. FNMOC wind speed data were available from http://las.pfeg.noaa.gov. Mooring data and support for this research was provided by the European research projects ANIMATE (Atlantic Network of Interdisciplinary Moorings and Time-for Europe), MERSEA (Marine Environment and Security for the European Sea), EUR-OCEANS (European Network of Excellence for Ocean Ecosystems Analysis) and EuroSITES grant agreement EU 202955. The work was also supported through the Natural Environment Research Council (NERC), UK, project Oceans 2025 and National Capability. The PAP-SO also contributes to the EU funded FixO3 project EU 312463 and the NERC Greenhouse Gas TAP NE/k00249x/1. D. Turk was supported by the Canada Excellence Research Chair (CERC) in Oceans Science and Technology. LDEO contribution number 7768 .

Edited by: J. Kaiser 


\section{References}

Behrenfeld, M. J., O’Malley, R. T., Siegel, D. A., McClain, C. R., Sarmiento, J. L., Feldman, G. C., and Milligan, A. J.: Climatedriven trends in contemporary ocean productivity, Nature, 444, 752-755, 2006.

Bennington, V., McKinley, G. A., Dutkiewicz, S., and Ullman, D.: What does chlorophyll variability tell us about export and air-sea $\mathrm{CO}_{2}$ flux variability in the North Atlantic?, Global Biogeochem. Cy., 23, GB3002, doi:10.1029/2008GB003241, 2009.

DeGrandpre, M. D., Hammar, T. R., Smith, S. P., and Sayles, F. L.: In situ measurements of seawater $p \mathrm{CO}_{2}$, Limnol. Oceanogr., 40, 969-975, 1995.

Dickson, A. G.: Standard potential of the $\left(\mathrm{AgCl}(\mathrm{s})+1 / 2 \mathrm{H}_{2}(\mathrm{~g})=\right.$ $\mathrm{Ag}(\mathrm{s})+\mathrm{HCl}(\mathrm{aq}))$ cell and thedissociation constant of bisulfate ion in synthetic sea water from 273.15 to $318.15 \mathrm{~K}$, J. Chem. Thermodyn., 22, 113-127, doi:10.1016/0021-9614(90)90074-Z, 1990.

Dickson, A. G., Sabine, C. L., and Christian, J. R.: Guide to Best Practices for Ocean $\mathrm{CO}_{2}$ Measurements, PICES Special Publication 3, Sidney, British Columbia, 191 pp., 2007.

Donat, M. G., Renggli, D., Wild, S., Alexander, L. V., Leckebusch, G. C., and Ulbrich, U.: Reanalysis suggests long-term upward trends in European storminess since 1871, Geophys. Res. Lett., 38, L14703, doi:10.1029/2011GL047995, 2011.

EuroSITES: European Ocean Observatory Network, http://www. eurosites.info/pap, last access: August 2014.

Fiedler, P. C.: Comparison of objective descriptions of the thermocline, Limnol. Oceanogr.-Meth., 8, 313-325, 2010.

Field, C. B., Behrenfeld, M. J., and Randerson, J. T.: Primary production of the biosphere: integrating terrestrial and oceanic components, Science, 281, 237-240, 1998.

González-Dávila, M., Santana-Casiano, J. M., Rueda, M. J., Llinas, O., and González-Dávila, E. F.: Seasonal and interannual variability of sea-surface carbon dioxide species at the European Station for Time Series in the Ocean at the Canary Islands (ESTOC) between 1996 and 2000, Global Biogeochem. Cy., 17, 1076, doi:10.1029/2002gb001993, 2003.

Hartman, S. E., Larkin, K. E., Lampitt, R. S., Lankhorst, M., and Hydes, D. J.: Seasonal and inter-annual biogeochemical variations in the Porcupine Abyssal Plain 2003-2005 associated with winter mixing and surface circulation, Deep-Sea Res. Pt. II, 57, 1303-1312, 2010.

Hartman, S. E., Lampitt, R. S., Larkin, K. E., Pagnani, M., Campbell, J., Gkritzalis, A., and Jiang, Z. P.: The Porcupine Abyssal Plain fixed-point sustained observatory (PAP-SO): variations and trends from the Northeast Atlantic fixed-point time-series, ICES J. Mar. Sci., 57, 776-783, 2012.

Henson, S., Lampitt, R., and Johns, D.: Variability in phytoplankton community structure in response to the North Atlantic Oscillation and implications for organic carbon flux, Limnol. Oceanogr., 57, 1591-1601, doi:10.4319/lo.2012.57.6.1591, 2012.

Holte, J. and Talley, L.: A New Algorithm for Finding Mixed Layer Depths with Applications to Argo Data and Subantarctic Mode Water Formation, J. Atmos. Ocean. Tech., 26, 1920-1939, 2009.

Hurrell, J. W.: Decadal trends in the North Atlantic oscillation: regional temperatures and precipitation, Science, 269, 676-679, 1995.

Hydes, D. J., Wright, P. N., and Rawlinson, M. B.: Use of a wet chemical analyser for the in situ monitoring of nitrate, Chemi- cal sensors in Oceanography, in: Chemical Sensors in Oceanography, edited by: Varney, M., Gordon and Breach, Amsterdam, 95-105, 2000.

Jiang, Z.-P., Hydes, D. J., Tyrrell, T., Hartman, S. E., Hartman, M. C., Dumousseaud, C., Padin, X. A., Skjelvan, I., and González-Pola, C.: Key controls on the seasonal and inter- annual variations of the carbonate system and air-sea $\mathrm{CO}_{2}$ flux in the Northeast Atlantic (Bay of Biscay), J. Geophys. Res.-Oceans, 118, 785-800, 2013.

Jiang, Z.-P., Hydes, D. J., Tyrrell, T., Hartman, S. E., Hartman, M. C., Campbell, J. M., Johnson, B. D., Schofield, B., Turk, D., Wallace, D., Burt, W., Thomas, H., Cosca, C., and Feely, R.: Application and assessment of a membrane-based $p \mathrm{CO}_{2}$ sensor under field and laboratory conditions, Limnol. Oceanogr.-Meth., 12, 264-280, 2014.

Kara, A. B., Rochford, P. A., and Hurlburt, H. E.: An optimal definition for ocean mixed layer depth, J. Geophys. Res., 105, 1680316821,2000

Körtzinger, A., Send, U., Lampitt, R. S., Hartman, S., Wallace, D. W. R., Karstensen, J., Villagarcia, M. G., Llinás, O., and DeGrandpre, M. D.: The seasonal $p \mathrm{CO}_{2}$ cycle at $49^{\circ} \mathrm{N} / 16.5^{\circ} \mathrm{W}$ in the northeastern Atlantic Ocean and what it tells us about biological productivity, J. Geophys. Res., 113, C04020, doi:10.1029/2007jc004347, 2008.

Lampitt, R. S., Bett, B. J., Kiriakoulis, K., Popova, E., Ragueneau, O., Vangriesheim, A., and Wolff, G. A.: Material supply to the abyssal seafloor in the Northeast Atlantic, Prog. Oceanogr., 50, 27-63, 2001.

Lavigne, H. and Gattuso, J.-P.: Seacarb: seawater carbonate chemistry with $\mathrm{R}, \mathrm{R}$ package version 2.4., available at: http://CRAN. R-project.org/package $=$ seacarb, last access: January 2014, edited 2011.

Lee, K., Tong, L. T., Millero, F. J., Sabine, C. L., Dickson, A. G., Goyet, C., Park, G. H., Wanninkhof, R., Feely, R. A., and Key, R. M.: Global relationships of total alkalinity with salinity and temperature in surface waters of the world's oceans, Geophys. Res. Lett., 33, L19605, doi:10.1029/2006g1027207, 2006.

Longhurst, A.: Ecological geography of the sea, Ecological Geography of the Sea Series, 2nd Edn., Academic Press, San Diego, 560 pp., 2006.

Lueker, T. J., Dickson, A. G., and Keeling, C. D.: Ocean $p \mathrm{CO}_{2}$ calculated from dissolved inorganic carbon, alkalinity, and equations for $\mathrm{K}-1$ and $\mathrm{K}-2$ : validation based on laboratory measurements of $\mathrm{CO}_{2}$ in gas and seawater at equilibrium, Mar. Chem., 70, 105-119, 2000.

McGillicuddy, D. J., Robinson, A. R., Siegel, D. A., Jannasch, H. W., Johnson, R., Dickey, T. D., McNeil, J., Michaels, A. F., and Knap, A. H.: Influence of mesoscale eddies on new production in the Sargasso Sea, Nature, 394, 263-266, 1998.

McKinley, G. A., Fay, A. R., Takahashi, T., and Metzl, N.: Convergence of atmospheric and North Atlantic carbon dioxide trends on multidecadal timescales, Nat. Geosci., 4, 606-610, 2011.

Montegut, C. D., Madec, G., Fischer, A. S., Lazar, A., and Iudicone, D.: Mixed layer depth over the global ocean: An examination of profile data and a profile-based climatology, J. Geophys. Res., 109, C12003, doi:10.1029/2004JC002378, 2004.

Monterey, G. and Levitus, S.: Seasonal variability of mixed layer depth for the World Ocean, NOAA NESDIS Atlas, US Government Printing Office, Washington, DC, 5 pp., 1997. 
Nightingale, P. D., Malin, G., Law, C. S., Watson, A. J., Liss, P. S., Liddicoat, M. I., Boutin, J., and Upstill-Goddard R. C.: In situ evaluation of air-sea gas exchange parameterizations using novel conservative and volatile tracers, Global Biogeochem. Cy., 14, 373-387, doi:10.1029/1999GB900091, 2000.

Padin, X. A., Castro, C. G., Ríos, A. F., and Pérez, F. F.: Oceanic $\mathrm{CO}_{2}$ uptake and biogeochemical variability during the formation of the Eastern North Atlantic Central water under two contrasting NAO scenarios, J. Marine. Syst., 84, 96-105, 2011.

Painter, S. C., Pidcock, R. E., and Allen, J. T.: A mesoscale eddy driving spatial and temporal heterogeneity in the productivity of the euphotic zone of the Northeast Atlantic, Deep-Sea Res. Pt. II, 57, 1281-1292, 2010.

Perez, F. F. and Fraga, F.: The $\mathrm{pH}$ measurements in seawater on the NBS scale, Mar. Chem., 21, 315-327, 1987.

Prytherch, J., Yelland, M. J., Pascal, R. W., Moat, B. I., Skjelvan, I., and Neill, C. C.: Direct measurements of the $\mathrm{CO}_{2}$ flux over the ocean: development of a novel method, Geophys. Res. Lett., 37, L03607, doi:10.1029/2009GL041482, 2010.

Redfield, A. C.: The biological control of chemical factors in the environment, Am. Sci., 64, 205-221, 1958, 1958.

Sambrotto, R. N., Savidge, G., Robinson, C., Boyd, P., Takahashi, T., Karl, D. M., and Codispoti, L.: Elevated consumption of carbon relative to nitrogen in the surface ocean, Nature, 363, 248250, 1993

Schuster, U. and Watson, A. J.: A variable and decreasing sink for anthropogenic $\mathrm{CO}_{2}$ in the North Atlantic, J. Geophys. Res., 112, C1106, doi:10.1029/2006JC003941, 2007.

Schuster, U., Watson, A. J., Bates, N. R., Corbiere, A., Gonzalez-Davila, M., Metzl, N., Pierrot, D., and SantanaCasiano, M.: Trends in North Atlantic sea-surface $f \mathrm{CO}_{2}$ from 1990 to 2006, Deep-Sea Res. Pt. II, 56, 620-629, doi:10.1016/j.dsr2.2008.12.011, 2009.
Skjelvan, I., Falck, E., Rey, F., and Kringstad, S. B.: Inorganic carbon time series at OceanWeather Station $\mathrm{M}$ in the Norwegian Sea, Biogeosciences, 5, 549-560, doi:10.5194/bg-5-549-2008, 2008.

Takahashi, T., Sutherland, S. C., Sweeney, C., Poisson, A., Metzl, N., Tilbrook, B., and Bates, N.: Global sea-air $\mathrm{CO}_{2}$ flux based on climatological surface ocean $p \mathrm{CO}_{2}$, and seasonal biological and temperature effects, Deep-Sea Res. Pt. II, 49, 1601-1622, 2002.

Takahashi, T., Sutherland, S. C., Wanninkhof, R., Sweeney, C., Feely, R. A., Chipman, D. W., Hales, B., Friederich, G., Chavez, F., Sabine, C., Watson, A., Bakker, D. C. E., Schuster, U., Metzl, N., Yoshikawa-Inoue, H., Ishii, M., Midorikawa, T., Nojiri, Y., Kortzinger, A., Steinhoff, T., Hoppema, M., Olafsson, J., Arnarson, T. S., Tilbrook, B., Johannessen, T., Olsen, A., Bellerby, R., Wong, C. S., Delille, B., Bates, N. R., and de Baar, H. J. W.: Climatological mean and decadal change in surface ocean $p \mathrm{CO}_{2}$, and net sea-air $\mathrm{CO}_{2}$ flux over the global oceans, Deep-Sea Res. Pt. II, 56, 554-577, doi:10.1016/j.dsr2.2008.12.009, 2009.

Thomson, R. E. and Fine, I. V.: Estimating Mixed Layer Depth from Oceanic Profile Data, J. Atmos. Ocean. Tech., 20, 319-329, 2003.

Wanninkhof, R.: Relationship between wind-speed and gasexchange over the ocean, J. Geophys. Res., 97, 7373-7382, doi:10.1029/92JC00188, 1992.

Weiss, R. F.: Carbon dioxide in water and seawater: the solubility of a non-ideal gas, Mar. Chem., 2, 203-215, doi:10.1016/0304 4203(74)90015-2, 1974.

Williams, R. G., McLaren, A. J., and Follows, M. J.: Estimating the convective supply of nitrate and implied variability in export production over the North Atlantic, Global Biogeochem. Cy., 14, 1299-1313, 2000. 